\title{
Deflagar o zero: observador e linguagem em Inserçóes em Circuitos Ideológicos
}

Victor Hermann Mendes Pena

UFMG

\begin{abstract}
Resumo
O presente artigo discute a obra Inserçôes em Circuitos Ideológicos, de Cildo Meireles, sob o ponto de vista do ato criativo, com enfoque na questáo do espectador, e da linguagem, com destaque à teoria da fala mítica, de Roland Barthes. A partir dessa perspectiva, pretende-se uma análise pormenorizada da obra, discutindo as diferenças entre o Projeto Cédula e o Projeto Coca-Cola, no que diz respeito ao papel do observador, a noção de "circuito", e o modo de combate à alienação ideológica.
\end{abstract}

Palavras-chave: Espectador; Inserçôes em Circuitos Ideológicos; Cildo Meireles.

\begin{abstract}
The present paper discuss the artwork Inserçôes em Circuitos Ideológicos, by Cildo Meireles, from the point of view of the creative act, with emphasis in the importance of the spectator; and language, focusing the theory of myth, by Roland Barthes. By utilizing this framework, a detailed analysis of the work is made, discussing the differences between Projeto Coca-Cola and Projeto Cédula regarding the role of spectator; the notion of 'circuit'; and ways of overcoming ideological alienation.
\end{abstract}

Keywords: Spectator; Inserçóes em Circuitos Ideológicos; Cildo Meireles. 


\section{Introduçáo}

Questóes acerca do papel do espectador sempre foram centrais para o desenvolvimento da arte e suas novas atribuiçôes compóem a força motriz da arte contemporânea. Cildo Meireles é um dos principais propositores do tema, que considera basilar para seu trabalho:

Toda minha atuação como trabalhador da arte está orientada por esta ideia: a de que não existe um observador isento, mas um sujeito que está no meio de um processo de pensamento, que deve acompanhar esse processo, vivê-lo, manipulá-lo, e náo somente observá-lo. ${ }^{1}$

Cildo parte do pressuposto de que obras de arte não podem ser separadas do ato de observar. Não há autonomia do conteúdo artístico face aos interesses do observador, uma vez que ele está sempre implicado em um processo contínuo de pensamento. A observação não tem início no momento em que o espectador se depara com uma obra, ela surge entremeio. Assim como o artista, o observador implica sempre no ato criativo sua curiosidade e sua experiência.

\section{Dialética Espectador-Consumidor}

Inserçóes em Circuitos Ideológicos é uma obra central para repensar o ato criativo. ${ }^{2}$ A obra retoma a perspectiva inaugurada pelo readymade de Duchamp, de uma criação artística fora dos limites tradicionais da estética - beleza, estilo, autoria, objeto único. A novidade, segundo o consenso da fortuna crítica, seria o reconhecimento de que, para além da estética, há a política, onde o artista procuraria travar uma nova batalha. Ao procurar escapar dos fluxos convencionais de troca e observação de objetos artísticos, a obra objetivaria a formação de um novo público autônomo, interessado em intervir diretamente nas situaçôes de seu tempo.

\footnotetext{
Nessa proposta, não há um publico strictu sensu (no sentido de observação, de passividade frente à grande e genial obra de arte) ou testemunhas oculares, mas agentes. Agentes envolvidos numa situação dinâmica que investe sobre o mundo, aí inscrevendo possibilidades de crítica, subjetividade e questionamentos. $^{3}$
}

Uma das situações levantadas por Inserçôes em Circuitos Ideológicos é o consumo. Aqui, a associação original entre readymade e mercadoria é recolocada sob nova ótica: náo apenas do ponto de vista do artista que questiona os meios de criação e cooptação; mas também do espectador, que se vê im-
1 MEIRELES, Cildo; SCOVINO, Felipe (org.). Cildo Meireles - Entrevistas, 2009, p.29. Grifo do autor.

2 "O ato criador não é executado pelo artista sozinho; o público estabelece o contato entre a obra de arte e o mundo exterior, decifrando e interpretando suas qualidades intrínsecas e, desta forma, acrescenta sua contribuição ao ato criador”. DUCHAMP, Marcel. "O Ato Criador", 2004, 73.

3 SCOVINO, Felipe. "A ironia e suas estratégias na obra de Cildo Meireles”. Arte \& Ensaios, Revista do Programa de Pós-Graduação em Artes Visuais EBA, 2007, p.102. 
4 AGAMBEN, Giorgio. $O$ homem sem conteúdo, 2012. p.53.

5 BARTHES, Roland. Mitologias, 1972 , p. 162 . pelido a questionar tanto o meio de acesso a objetos artísticos e/ou mercadológicos, quanto o modo de fruição. Se Duchamp combatera a alienação do artista pelo estilo e "artesanato manual" aproximando-o do engenheiro industrial, Cildo aproxima a situaçáo do espectador àquela vivida pelo consumidor, com vistas a problematizar a alienaçáo simultaneamente nos níveis estético e ideológico.

Tradicionalmente, a questão da alienação do espectador em relação ao objeto artístico pode ser descrito, de acordo com o filósofo Giorgio Agamben, como uma espécie de "enigma inquietante":

\footnotetext{
Ele está diante de algo em que tem a impressão de reencontrar a sua verdade mais íntima e, todavia, não pode se identificar com ela, porque a obra de arte é, justamente, como dizia Kant, 'aquilo que, mesmo que seja conhecido perfeitamente, não se tem, ainda assim, a capacidade de produzir'. ${ }^{4}$
}

Inserçôes em Circuitos Ideológicos permite estender essa noção para a relação entre mercadoria e consumidor. Este encontra-se num impasse similar: também é induzido a reconhecer na mercadoria o valor supremo e sua verdade mais íntima, expressada a sua potência no objeto e a partir deste objeto. E, não tendo qualquer papel na sua criação, o livre princípio criativo do mercado se eleva entre o consumidor e sua verdade. Os dois circuitos - de arte e de mercadoria - têm por finalidade a reprodução de um modo passivo de recepção de seus conteúdos estético e/ou ideológico. Este é o ponto de partida para uma dialética intricada entre estética e mercado elaborada pela obra. O sujeito encontra-se em estado indeterminado: diante de uma CocaCola das Inserçôes, ele é, potencialmente, artista, espectador e consumidor. Pode tanto ser capturado pelo circuito da Coca-Cola quanto ser o propositor de um novo circuito de troca de informaçóes.

Esta indeterminabilidade da condição do sujeito em relação às Inserçôes deve ser considerada, também, no plano da linguagem, na medida em que a relação triádica do ato de comunicação (emissor-conteúdo-receptor; ou ainda, artista-obra-espectador; e produtor-mercadoria-consumidor) é subvertida. Nossa hipótese é a de que a desestabilização do ato de comunicação tradicional, quando os papéis dos atores deixam de ser perfeitamente distinguíveis, é fundamental para tornar o circuito ideológico vulnerável ao ato de inserção.

\section{Teoria da Fala Mítica}

A teoria duchampiana do ato criativo teve o mérito de encarar o processo de significação em arte como irredutivelmente linguístico, no qual os três entes envolvidos guardam relativa independência entre si. O "coefi- 
ciente artístico" de uma obra resulta precisamente dessa relação não linear entre as intenções do artista; o que é expresso de modo não intencional pela matéria da obra e pelos interesses do espectador. A novidade da proposta de Duchamp consistira em dar ênfase ao papel do espectador, a quem caberia, em tese, "extrair o melado", a "palavra final" do ato criativo; e a obra de Cildo teve o mérito de dar a tal ênfase uma conotação política.

Entretanto, se o caráter de ato de linguagem de uma criação artística parece evidente, como considerar um objeto de consumo enquanto ato de linguagem? A teoria do mito, de Roland Barthes, nos ajuda a elucidar algumas questóes em jogo na obra de Cildo. A mercadoria, para Barthes, é utilizada pela sociedade burguesa como uma forma especializada, dentre várias outras, para veicular mitos. Para o filósofo, mito é fala - mas uma fala cuidadosamente escolhida pela história, portanto, com forte carga ideológica. Fala das coisas, nunca as coisas; canta-as, ao invés de agi-las. Isto é, sempre uma metalinguagem que investe contra a linguagem-objeto: uma pseudo-physis ou natureza artificial, "o movimento pelo qual a burguesia transforma a realidade do mundo em imagem do mundo, a História em Natureza”. 5 A função da fala mítica seria "evacuar o real: literalmente, o mito é um escoamento incessante, uma hemorragia, ou, se se prefere, uma evaporação; em suma, uma ausência sensível." 6

Para Barthes, a matéria-prima da fala mítica seria sempre o último termo da cadeia de significação da linguagem-objeto: o sentido - expresso pelo signo, total associativo entre significante e significado. Aqui, os versos de Cartola são cristalinos no que tange à relação entre significante, significado e signo/sentido: as rosas não falam (significante), simplesmente exalam (significado), o perfume que roubam de ti, ai... (relação associativa; signo/ sentido). Há entre significante e significado elos de ação: Cartola fala não das rosas, mas as rosas que, mesmo mudas, de modo insondável teimam em se associar, no ato de fala, à amada. ${ }^{7}$ Contudo, quando as mesmas rosas são convertidas no hábito burocrático de se presentear mulheres no dia oito de março, vê-se precisamente como o mito subtrai o sentido da linguagem-objeto, impinge-lhe uma hemorragia do real e, por fim, confere-lhe uma aparência "normal", "natural". Em outras palavras: uma vez no mito, tratam-se sempre de rosas roubadas. A operação metalinguística da fala mítica consistiria em, precisamente, roubar o sentido da linguagem-objeto mediante uma curiosa prestidigitação: o sentido, termo último da linguagem-objeto, sofre uma regressão, retornando ao estatuto de forma vazia, de significante.

O mito, portanto, estabelece relaçóes não de verdade, mas de utilidade; vale por ser útil; e dispóe para si de todos os fatos e atos da linguagem-objeto tal qual alguém vagando no supermercado. O objetivo do mito seria comunicar um valor. Contudo, paradoxalmente, ainda que o mito tente passar por fato natural, haverá sempre uma instabilidade, uma precariedade própria ao mito, por dois motivos: primeiro, porque o sentido roubado
6 Ibidem, p. 163.

7 O exemplo é imperfeito quando carrega certa carga mítica: por tratar-se de arte, um samba, pode ser tomado como ficção e, assim, ser-lhe adicionado uma segunda camada de significação puramente metalinguística. Contudo, convém notar como Cartola escapa habilmente às convençóes do gênero romântico ao distinguir o significante mudo e significado "exalado". 
8 BARTHES, Roland. Mitologias, 1972, p. 161. Grifo do autor.

9 A campanha comercial da Pepsi, estrelada pela celebridade Kendall Jenner, em 2017, causou polêmica ao representar um grupo de jovens manifestantes dividindo - e celebrando - uma Pepsi com os policiais que ali estavam na função de reprimi-los. Sob forte protesto, a campanha saiu do ar. sempre poderá ser recuperado em sua condição original de linguagem-objeto; segundo, porque o valor veiculado pelo mito é sempre relativo, expresso pelo coeficiente de utilidade em relação aos interesses históricos da sociedade burguesa. Portanto, a aparência natural do mito corresponderia não à sua consistência interna, sempre precária, mas ao coeficiente de despolitização do real de que é capaz. Esta seria, em suma, a vocação para uma ideologia anônima do mito:

[...] mergulhada nessa ideologia anônima: a nossa imprensa, o nosso teatro [...] a cozinha com que sonhamos, o vestuário que usamos, tudo, na nossa vida cotidiana é tributário da representação que a burguesia criou para ela e para nós, das relaçóes entre o homem e o mundo. Estas formas "normalizadas" chamam pouca atenção devido, justamente, à sua grande extensão, a sua origem pode perder-se à vontade; gozam de posição intermediária: não sendo nem diretamente políticas, nem diretamente ideológicas, vivem pacificamente entre a ação dos militantes e o contencioso dos intelectuais: mais ou menos abandonadas por uns e por outros, juntam-se à massa enorme do indiferenciado, do insignificante, em suma, da natureza. [...] O fato burguês é assim absorvido num universo indistinto cujo único habitante é o Homem Eterno, nem proletário nem burguês. ${ }^{8}$

A força do mito consistiria em, precisamente, tramar para si inúmeras estratégias de naturalizaçáo. Com vocaçáo anônima, pode absorver como "natural" até mesmo a tentativa de sua desmistificação.

\section{Extensáo, Linguagem-Objetiva}

O slogan diz: Drink Coke. Mas, qual Coke? Aquela, em cujo sabor ainda é possível distinguir o conjunto de tensões que marcaram a industrialização do campo pelo green capitalism; ou a radical desestabilização, em escala global, do sensível sob efeito de novas intensidades químicas? Ou esta outra Coke, que calculadamente decantara o cenário acima descrito para extrair o insumo mais perfeito, o seu verdadeiro ingrediente secreto, o mito do american way of life? Hey, babe: beba cola, babe coca - uma Pepsi para o policial. ${ }^{9}$

A Teoria do Mito, de Roland Barthes, permite elucidar alguns pontos de Inserçóes em Circuitos Ideológicos, a começar pela diferenciação do Projeto Coca-Cola do Projeto Cédula. A diferença entre os suportes escolhidos para inserção não é apenas metaforicamente motivada ou informada por um mesmo método conceitual aplicado a objetos distintos. Nossa hipótese é de que elas intervêm de modo completamente diverso na estrutura da linguagem mítica. 
Com efeito, a garrafa de coca é um mito burguês "imperfeito" na medida em que não consegue ser integralmente absorvida na massa enorme da ideologia anônima cotidiana. Pinçada cuidadosamente pelo marketing no oceano de bebidas químicas industriais, a Coca-Cola combina o valor mítico ao valor de marca. Segundo a socióloga Naomi Klein, no exato momento em que empresas como Coca-Cola, Disney e McDonald's entenderam que vendem, na verdade, ideias, e não produtos - diríamos: vendem mitos -, elas adquirem novas vulnerabilidades. ${ }^{10}$ São efeitos colaterais do valor de marca, que podemos considerar como um modo de "monetizar" o valor do mito. Para monetizá-lo, é necessário trazer o mito para primeiro plano e amplificá-lo. Ao apostar na associaçáo entre Coca-Cola e o American Way of Life como estratégia global de venda, a empresa acaba tornando mais visível o conjunto de decisóes que impuseram ao sentido original uma hemorragia calculada do real. Com isso, perde a imunidade que só o anonimato pode oferecer. Facilita o trabalho do mitólogo, que revela facilmente ao público o álibi. Como em Inserçóes, procedimentos rudimentares bastam para fazer de uma marca o veículo de sua crítica - uma inversão de letra, babe coca, ${ }^{11}$ é o suficiente para fazê-la representar o imperialismo yankee. Ao amplificar sua estrutura mítica pelos megafones do marketing, torna-se comparativamente mais fácil isolar o sentido usurpado pela marca e, assim, revelar ao público consumidor as deformaçóes políticas que produz.

Já a cédula tem plena vocação anônima. Não chama atenção de ninguém precisamente porque seu circuito ocupa máxima extensão; não aparenta ter valor em si porque é pura equivalência - vale somente pelo uso. No oceano das relaçóes cotidianas, perde-se de vista; poucos sabem dizer de onde vem o dinheiro, como é criado; e, diferentemente das rosas de Cartola, a mudez de seu significante jamais "exala" o sentido de sua origem: dinheiro é sempre mito. Em um certo sentido, dinheiro dá em árvore; em todo caso, a arte é uma verdadeira árvore de dinheiro.

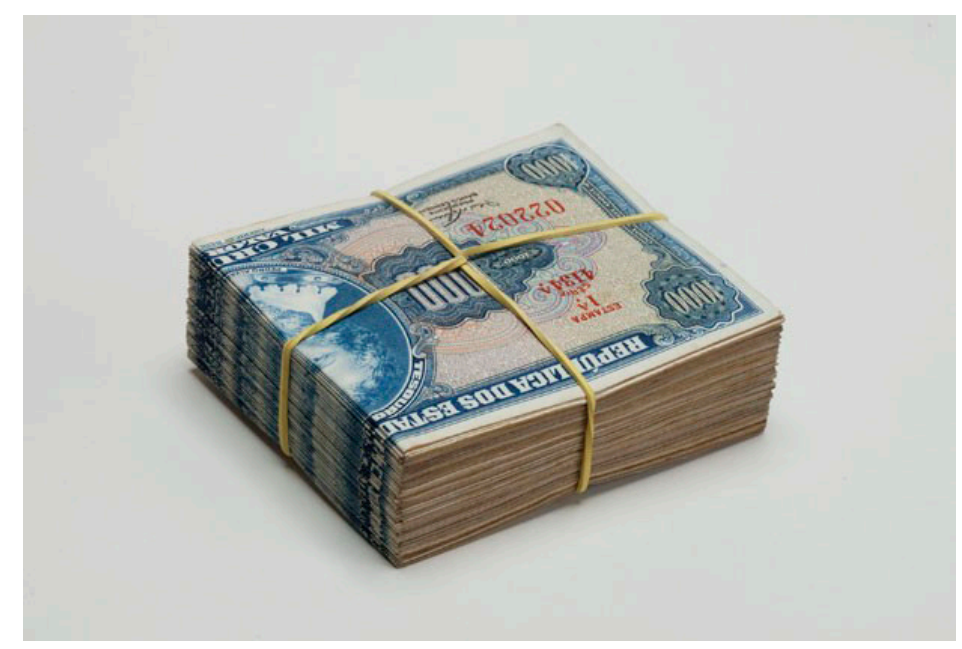

Cildo Meireles, Árvore de Dinheiro, 1969

Escultura composta de Maço de 100 notas de um Cruzeiro cujo valor de mercado é, pelo menos, 20 mil vezes maior.
10 Cf. KLEIN, Naomi; VINAGRE, Ryta. Sem logo: a tirania das marcas em um planeta vendido, 2002.

11 Décio Pignataria apud CAMPOS, Haroldo. Teoria da poesia concreta: textos críticos e manifestos 1950-1960, 1987, p. 88. 
A operação proposta por Cildo é precisa ao distinguir dinheiro e cédula. Distingui-las é fundamental quando se busca desestabilizar a relação de apropriação da linguagem-objeto pelo mito. Ainda que dificilmente seja percebida desse modo nas relaçôes cotidianas, uma cédula pode ser o último termo da linguagem-objeto; dinheiro, por sua vez, é sempre fala mítica. Naquela, é possível destacar o significante, mera superfície de papel, e o total associativo, resultante da impressão; nesta, já não importa se se trata de uma cédula ou de apenas um número na tela do caixa eletrônico. Quando esquecemos cédulas no bolso de uma calça jeans numa máquina de lavar, trata-se de um infortúnio que nos lembra da precariedade específica que marca a invenção desse sistema de trocas - fato que, ainda que de modo atenuado, nos remete de alguma maneira a seu rastro político. Contudo, quando jovens milionários acedem cigarros Marlboro com notas de 100, eles queimam o significante roubado para iluminar o dinheiro puro. Zero dólares.
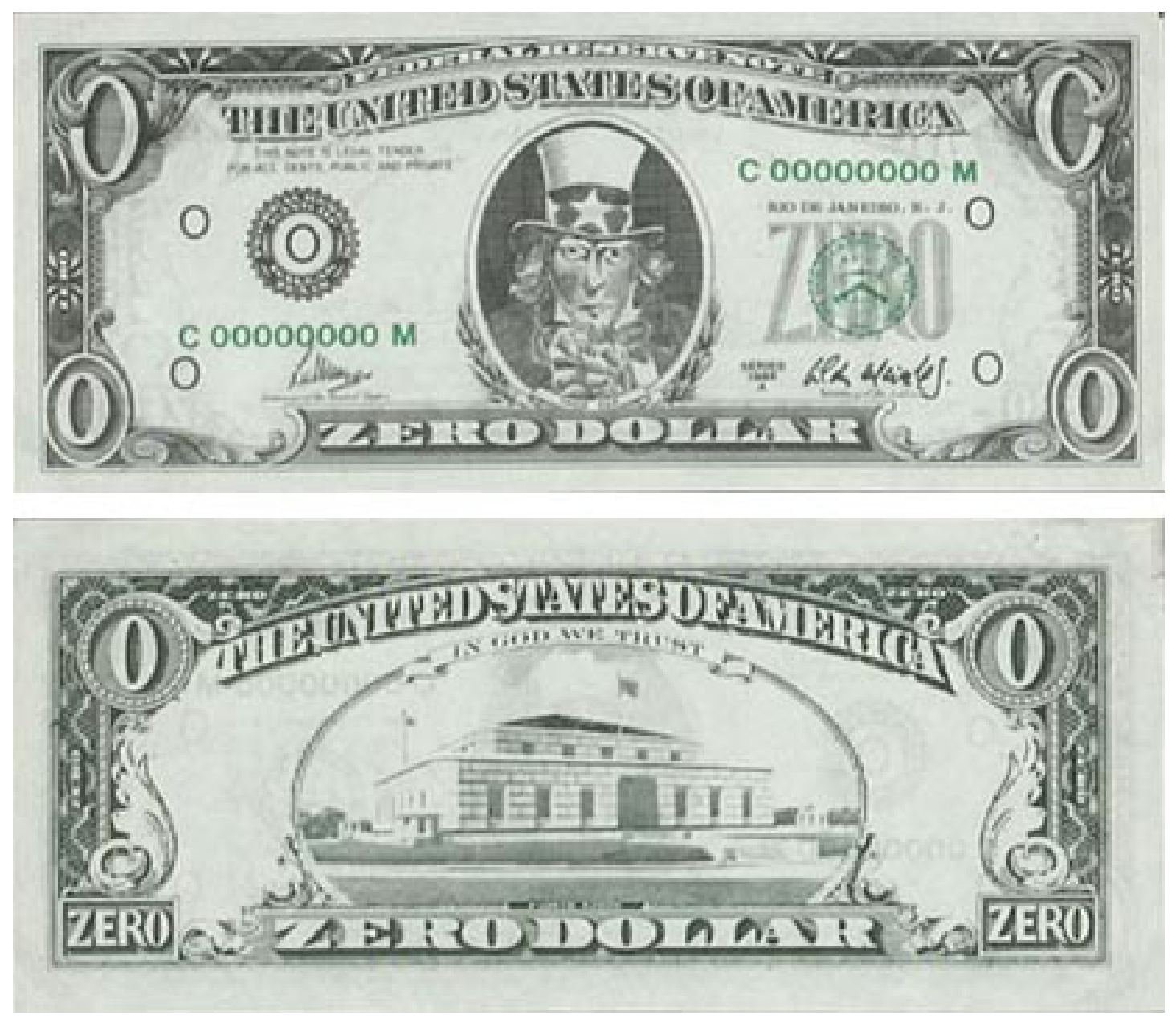

Zero Dólar - Cildo Meireles, 1974-8. Impressão em papel.

Procurar o significante da linguagem-objeto, ou ainda, revelar o sentido usurpado são estratégias de intervenção na fala mítica. No Projeto CocaCola, Cildo já havia tentado inserir-se no intervalo entre a linguagem-objeto 
e a fala mítica ao sugerir que uma garrafa poderia ser convertida em coquetel molotov. Entretanto, para um artista que chegara a proclamar "não mais trabalhar com a metáfora da pólvora - trabalhar com a pólvora mesmo", ${ }^{12}$ vale a pena examinar melhor o trajeto que segue do ato de inserção, na superfície da garrafa, do método de fabricação da bomba até a bomba efetivamente lançada. Imaginemos, então: uma bomba feita com garrafa de Coca-Cola - não qualquer uma, mas esta, grafada com instruçóes de sua própria destruição, esta que percorreu todo o circuito de produção, distribuição e comercialização, desafiando o controle. Não seria uma metáfora forte demais para sugerir que o conteúdo ideológico do mito fora totalmente desestabilizado? Já dizia o poeta: "porque não podes, sozinho, dinamitar a ilha de Manhattan." 13 O sentido da inserção ainda está preso à armadilha da fala mítica: um molotov de Coca-Cola parece, no plano metafórico, significar um poderoso ato de resistência quando, na verdade, não passaria de outro mito, mito de resistência. Cildo, ao propor uma garrafa de Coca-Cola portando as instruções de sua própria subversão, objetivava não o incremento de produção e uso de coquetéis molotov contra o sistema - para tal bastaria um panfleto. Isso, de certo modo, torna-a vulnerável à contemplação como mero objeto de arte. A poderosa operação realizada no campo estético é, no entanto, vulnerável à recuperação da fala mítica quando passa ao plano de açáo. A ideia de transformar uma Coca-Cola em coquetel molotov fala mais alto que o ato concreto de lançar um coquetel molotov com esta Coca-Cola que se tem em mãos. A 'consumação em chamas do Molotov' está para o ato de 'consumir Coca-Cola' assim como o imperialismo yankee está para o american way of life - isto é: cara e coroa de uma mesma moeda de cunho mítico. Em outras palavras, no Projeto Coca-Cola, algo do real subtraído pelo mito é novamente revelado através de um curto-circuito produzido pela obra que, entretanto, náo se mostra inteiramente capaz de subverter o sistema mítico que a energizara num primeiro momento. Algo de semelhante acontece quando Cildo inscreve nas garrafas, em inglês e português, a pergunta "Qual é o lugar de um trabalho de arte?" - uma proposta que, hoje, já fora completamente assimilada, roubada, pelas novas estratégias de "marketing de guerrilha" ${ }^{14}$. Ambas as inserções, desse modo, malogram em fomentar a invenção de um novo circuito - tanto a conversão da Coca-Cola em molotov ou em obra de arte não cumprem os requisitos de uma nova inserção e se esgotam no próprio, uma vez que já não re-atravessam o circuito ideológico tampouco re-alimentam o circuito de inserçóes em busca de novos parceiros.

O Projeto Cédula escapa melhor à fala mítica sem, contudo, furtar-se a questioná-la. Quando Cildo carimba numa cédula a questão "Quem Matou Herzog?", não parecem haver meios de, mediante resposta, se recuperar uma relação mítica com o dinheiro diante de interpretaçôes metafórico-fetichis-
12 MEIRELES, Cildo. Cildo

Meireles, 1981. p. 28.

13 ANDRADE, Carlos

Drummond de. "Elegia 1938", 1978, p. 107.

14 Um modo de compreender como o Projeto Coca-Cola náo escapa completamente à lógica do mito é comparando-o com as diversas "inserçốes" que a própria Coca-Cola tem feito em suas garrafas. Um bom exemplo é a campanha "Essa Coca-Cola é Fanta, e Daí?", ação elaborada pela agência DM9DDB, de Nizan Guanaes, na qual garrafas de Coca-Cola são envazadas com Fanta. Aludindo a uma expressão popular homofóbica, o rótulo questiona o consumidor sobre seus preconceitos. Como o Molotov de Coca-Cola, a mera sugestáo de que uma Fanta travestida de Coca-Cola exista, que possa ser consumida, parece satisfatória, sempre a nível imaginário, no que tange ao combate à homofobia quando, na verdade, é evidente o flagrante descompasso entre ações de marketing e políticas efetivas da indústria quanto ao tema - e nem precisamos ir longe, basta considerar a opção da própria agência em servir-se de sua criação para fabricar um anúncio da Revista Veja, tão criticada por seu flagrante conservadorismo em temas sexuais. $\mathrm{O}$ anúncio diz: "Sua Coca-Cola é 1.200.000 vezes mais Fanta na Veja" - será? Em todo caso, não seria de todo surpreendente se Nizan, com sua vaidade peculiar, nos perguntasse, enfim, "qual é o lugar da luta contra a homofobia?". 
15 MEIRELES, Cildo. Bravo Online, jul. 2006. Entrevista concedida a Fernando Oliva.

tas. Gastá-la, queimá-la, doá-la para a Anistia Internacional ou para grupos armados, ou ainda, quem sabe, simplesmente grafá-la com o nome do general do DOPS responsável logo abaixo: nenhuma ação realizada sobre esta cédula poderá satisfazer integralmente a pergunta que ela veicula. Em outras palavras, a inserção resiste melhor à fala mítica porque exclui a possibilidade de fim da comunicação. Ora, o mito será sempre um segundo sistema de significação, mas também o último: natural, mas também eterno. É o Molotov de Coca-Cola estampado numa T-Shirt. O Projeto Cédula não se limita a denunciar o conteúdo mítico; pelo contrário, trafega no vão entre linguagem-objeto e pseudo-physis como terceira linguagem: linguagem-objeti$v a$, de resistência, sem controle.

\footnotetext{
$\mathrm{Na}$ verdade, as Inserçóes em Circuitos Ideológicos nasceram da necessidade de se criar um sistema de circulação, de troca de informaçôes, que não dependesse de nenhum tipo de controle centralizado. Uma língua. Um sistema que, na essência, se opusesse ao da imprensa, do rádio, da televisão, exemplos típicos de media que atingem de fato um público imenso, mas em cujo sistema de circulação está sempre presente um determinado controle e um determinado afunilamento da inserção. ${ }^{15}$
}

O Projeto Cédula não se limita a denunciar certo conteúdo ideológico de determinado circuito, mas a instaurar um processo novo de comunicação arredio às estratégias mesmas de deformação ideológica. Se o ato de converter uma garrafa de Coca-Cola em bomba parece servir de ponto de conclusão do ato criativo; as inserçôes em papel-moeda parecem estar destinadas a um moto-contínuo, sem fim, sem paragem, perpétua comunicação incontrolável. Não são metáforas, não carregam a ironia deceptiva da panfletagem de esquerda (esta, que é também um mito, para Barthes, pois aceitara esconder seu verdadeiro nome, revolução). São literalmente cédulas a perguntar: Quem matou Herzog? Quem matou Herzog? Quem matou Herzog? A ênfase contra a dimensão sistêmica do mito investe o ato de comunicação com uma objetividade capaz de resistir à cooptação. Certamente, não se trata de, com a pergunta, insinuar que "o dinheiro assassinou Herzog", ainda que a obra nos convide a considerar que o dinheiro está ativamente implicado no assassinato. O que se urge mesmo saber é: qual a extensão deste ato homicida? Por isso, a obra escolhe o circuito de maior extensão de sua época, a circulação de dinheiro.

Mediante solidariedade anônima, cada pergunta tem o potencial de, teoricamente, recobrir a totalidade da extensão do circuito. Imaginemos, assim, todas as notas de cruzeiro ou real carimbadas com Quem Matou Herzog? $\mathrm{O}$ potencial de recobrir todo um circuito com uma nova informação torna a 
obra apta a combater a ideologia não apenas a nível do sentido, mas sobretudo no espaço. Recobrindo toda a extensão do fluxo de trocas de cédulas, a cada movimentação do circuito a pergunta é refeita. Contudo, se o valor de uma nota permanece o mesmo ao longo de todo o fluxo de trocas, o mesmo não acontece com a pergunta. A cada momento em que a pergunta é troca$\mathrm{da}$, a cada vez que o sujeito espectador-consumidor se depara uma e outra vez com ela, a cada novo e repetido ato de carimbar, o peso exercido pela pergunta sobre o circuito dobra. Em outras palavras, "Quem Matou Herzog?" ganha em densidade a cada movimento do sistema. A pergunta passa a escapar à lógica do circuito na medida em que não objetiva uma resposta única, um sentido ou gesto acessível à interpretação. Seu objetivo é a formação de densidades capazes de resistirem à lógica do circuito sobre o qual operam: lógica de entrada e saída, de sentido e forma-vazia, em suma, de deformação ideológica e alienação passiva.

A densidade objetivada pelo ato contínuo de (re)inserção não é, em absoluto, derivada de um suposto de desejo de estabelecer um diálogo com uma "populaçáo economicamente ativa" para "denunciar a ditadura". A obra não quer resignar-se ao ato de comunicação restrito do emissor-conteúdo-receptor. O limite do Projeto Cédula não é o tempo de duração do regime militar, a conclusão dos trabalhos da Comissão de Verdade, o fim da anistia. Em outras palavras, o limite da densidade não é a verdade ou a utilidade, a linha que traça do sentido ao mito. É o espaço. O que a obra procura são aliados encarniçados, habitantes do espaço, seres capazes de incorporar e manipular a densidade transformadora. Por isso, não cessa jamais de perguntar: Quem Matou Herzog? Quem Matou Herzog? Quem Matou Herzog?.

Sua ação transtorna não apenas o valor do mito mas, sobretudo, a extensão mesma do mito, o espaço onde o mito conquista seu anonimato e convive entre os homens com perfeita naturalidade. Em resumo, a obra inventa objetivamente em sua ação antimítica uma estratégia: primeiro, cartografar a ideologia enquanto circuito; segundo, operar uma linguagem resistente capaz de abalar não apenas o valor, mas o modo mesmo de cooptação via mito e de circulação de sua ideologia; terceiro, recobrir toda a extensão do circuito com uma contrainformação que jamais cede à cooptação, porque não tem ponto de paragem definido (não esgota seu interesse, não forma sentido) e porque náo cessa de ser reinserido a cada movimentação do circuito; por fim, formar densidades transformadoras que, sem recorrerem a um sentido pleno, transformam "inexplicavelmente" as relaçóes de força como na obra Eureka/Blindhotland (1970): 
16 BRITO, Ronaldo.

"Freqüência Imodulada", 1981, p. 8 .

17 Ainda hoje, cotidianamente, é palpável essa impressão de que o carimbo carrega algo mais que um rabisco, uma verdadeira agressáo que poderia por em risco a nota ou formalidade financeira que deve ser considerada. madeira passam a ter o mesmo peso de seis cubos de idêntica madeira. O chumbo infiltrado em um dos cubos aponta a presença da densidade transformadora: algo que não se vê ou toca e que muda 'inexplicavelmente' as relaçôes de força. ${ }^{16}$

\section{Carimbar o método}

Outro aspecto importante da obra é o carimbo que formaliza o método de inserção, onde estão inscritos o título da obra, o mecanismo de execução, a data e as iniciais do nome do artista. Cumpre dois fins: primeiro, prepara uma visibilidade artística para o objeto; segundo, convida o espectador ao ato de inserção. Torna, desse modo, incontornável o estado indeterminado do sujeito: tendo em mãos um objeto que é simultaneamente mercadoria e arte, cabe a ele decidir-se consumidor, espectador ou artista. $\mathrm{O}$ objeto causa incômodo na medida em que náo se permite apaziguar em nenhuma das situaçôes. Diferentemente das Brillo Box, não brilham simplesmente na gôndola do supermercado seu atraente anonimato; tampouco cintilam inertes, na galeria de arte, esta paradoxal anestesia que aceitara a hipótese do brilho. Quando deparamo-nos com Inserçóes em Circuitos Ideológicos, podemos até pensar estarmos diante de um objeto "recuperado" pelo museu. Mas, para isso, precisamos ter, primeiro, optado em sermos apenas espectadores; do contrário, se duvidarmos realmente de nossa condição, a relação da obra emoldurada com as cédulas que possuímos em nossas carteiras não será menos arbitrária que aquela entre um livro de Isaac Newton cuidadosamente repousado na estante da biblioteca e o automóvel estacionado na porta, isto é: estamos diante apenas do método preservado das vicissitudes da história, cabendo a nós, exclusivamente, decidir acerca da sua aplicação no presente.

E se o filosofo, diante das Brillo Box, optara deliberadamente esquecer o nome - caixas brilho -, as Inserçóes obrigam aos objetos declararem seu nome: isto é uma garrafa de Coca-Cola; isto é uma cédula de 20 reais. Os objetos devem passar esse constrangimento tanto no interior hermético do cubo branco quanto na selva dos mercados. E declaram, não para a abstração do "público", nem para o "mercado consumidor", mas para cada um que por ventura, na intimidade do toque, o encontre. No vão desse constrangimento - no zero desse sistema, diria Ronaldo Brito - uma terceira fala comunica objetivamente algo, contudo, que jamais chega a formar sentido pleno.

O ato solene de carimbar - corretamente associado pela crítica ao antigo hábito do banco central, transtornado por trocas incessantes de moedas engolidas pela inflação, de carimbar notas com novo valor ${ }^{17}$ - estabelece a última associação indigesta entre estética e economia: o gesto habitual do artista espelhado nas operaçóes burocráticas do Estado. Entre o estilo e a mecanicização reside um terceiro ato objetivo, assinado liminarmente com 
as iniciais do interventor participante. Rompe-se, desse modo, um circuito mais abrangente de alienação que impedia, de um lado, a apropriação integral da esfera da produção de si mesmo; e que, de outro, não cessava de poluir essa esfera com dejetos ideológicos produzidos em escala industrial. A repetição do ato de carimbar aborda a questão de modo radicalmente diverso de Warhol. Não celebra a assimilação da máquina pelo artista através de um trabalho perfeitamente repetitivo, mas calculadamente precário, que contrabalança aspectos estéticos e fabris para salvaguardar sua existência nos dois mundos. $\mathrm{O}$ ato de carimbar, apesar de gesto perfeitamente burocrático, contém em seu próprio mecanismo a produção de sua diferença, a antecipação de uma nova inserção não calculada, e nisto escapa às intenções da máquina. Ao tramar uma visibilidade artística para o objeto, Cildo também retoma a crítica da originalidade inaugurada pelos ready-mades, ao ressaltar a total ausência de "estilo" do artista, incapaz de ser reconhecido o seu modo particular de pensar sequer na pergunta que insere, afinal, "Yankees Go Home”, "Quem Matou Herzog?”, são todas frases perfeitamente redundantes no "grande bate-boca" ou na circulação oral de informaçôes.

A arte tinha de poder ser feita e curtida por qualquer pessoa tocada por ela. Tento sempre trabalhar com ideias as mais claras e reproduzíveis. Para mim, o trabalho ideal deve ter um grande coeficiente de informação nova dentro da forma mais redundante, isto é, mais coletivamente possuída. É o caso da nota de zero e das inserçóes. ${ }^{18}$
18 MEIRELES, Cildo; SCOVINO, Felipe (Org.). Encontros: Cildo Meireles, 2009, p.29.

O carimbo contendo o método, portanto, é o que assegura a cada inserção a possibilidade de ser percebida como tal, ação multitudinária, a nível estético e político. Provoca o "receptor" a percebê-la em contrafluxo à própria movimentação do sistema, na medida em que exige que se contemple o conjunto de decisóes que a fizeram existir, a começar pelo próprio ato de carimbar, sem qualquer véu de naturalidade.

\section{Inserir-se}

É bastante sintomático do estado atual da crítica de arte o fato de não ser prática recorrente o ato de criar inserçóes de própria lavra com o objetivo de examinar melhor a obra. Chega a ser lamentável, neste ponto, a falta de curiosidade. A escassez de relatos de experiências "individuais" com a obra contrasta com a postura, sempre bem-intencionada, dos críticos em apontar os "jovens artistas" que mantêm viva a chama das Inserçôes; mesmo que isso implique certa contradição com o consenso de que as Inserçóes se destinam ao homem anônimo, comum. Ainda assim, não é raro que alguns críticos 
19 MELENDI, Maria Angélica. "Garrafas no mar, da urgência à desesperança”, 2002.

20 Curiosamente, com o caso do desaparecimento do pedreiro Amarildo no subúrbio do Rio de Janeiro, as Inserçóes em Circuito Ideológico retornaram à cena, mostrando a força que guardam para toda e qualquer situaçáo de injustiça. sintam necessidade de apontar as limitações intrínsecas do ato de inserção, sua banalidade táo facilmente recuperável pelos modos tradicionais de legitimação. Preferem reservar para si tarefa mais modesta: dar voz às cantilenas do mito do artista enquanto revolucionário solitário que demanda o impossível.

\footnotetext{
Notas carimbadas por artistas não diferem, em essência, daquelas em que anônimos deixam telefones ou mensagens, a fachada da oficina mecânica grafitada é igual à de tantas oficinas da cidade, as flores no chão ou no canteiro poderiam obedecer ao capricho de qualquer um. A instância institucional - seja ela galeria, museu, catálogo, publicação - legitimaria essas obras. Devemos lembrar que, ante a dificuldade de julgá-las a partir de princípios estéticos, políticos ou didáticos, apenas poder-se-ia aferir sua eficácia imediata, quase sempre muito modesta no momento de sua execução. Mas se nos colocarmos frente a esses trabalhos da mesma maneira que seus autores - uma maneira fluida, porosa, instável, desesperançada enfim -, talvez possamos vê-los e senti-los. Não devemos esperar muito deles no aqui e no agora, apenas vislumbrar pequenas vibraçóes nas arestas do real - esse espaço em ruínas onde tudo se contamina e se deteriora - que nos façam suspeitar que alguma coisa está por acontecer. ${ }^{19}$
}

Nesse caso, digo que há muito tempo aceitei a provocação de Cildo. E se algum bibliômano me lê, conto que são pelo menos 400 cédulas, doze carimbos ao total. Não fiz o Projeto Coca-Cola pois não domino a técnica do decalque. E não mostro as cédulas pois ainda não sou defunto autor.

Em todo caso, faço breve relato. Notei, primeiro, que é dificílimo escapar da armadilha da metáfora, do mito; e não sei se cheguei a ser bem-sucedido. Ao mesmo tempo em que procurava por frases redundantes, coletivamente possuídas, algo me dizia que "Fora Temer", por exemplo, não bastava. Foi assim que compreendi melhor a urgência - e a dificuldade de ser urgente - que levara à pergunta "Quem matou Herzog?”" Inserçôes, em última instância, não se resume a uma crítica ao sistema, encarniçada, ela luta no espaço: trata-se de resistir às formas mais insidiosas de injustiça. Por fim, comecei a experimentar simplesmente piadas e oximoros, o que trazia grande diversão aos envolvidos.

Com o tempo, passei a considerar verdadeiramente belo (belo, sim) não exatamente as informaçóes grafadas, a possibilidade de se comunicar anonimamente com um "mar de gente"; tampouco o gosto que se pega em fazê-las, a sutilíssima adrenalina que nos acomete quando as trocamos, ou ainda, as conversas que, ocasionalmente, se estabelecem quando as reinserimos. Tudo isso é também bonito; mas o que assombra - e o que chamamos 
de arte não é precisamente modo como se trama a aparição do assombro? - é o modo como, ao trocar uma nota, o zero a menos torna-se visível, palpável, denso.

O desejo é interferir no Sistema mediante uma esquisita manobra: aparecer como zero, ponto cego da hierarquia, imponderável dado que a máquina não registra e não calcula. A paradoxal fórmula da "inserção" seria: a possibilidade de emergência do impossível. A sua paradoxal 'verdade' é a de que o impossível move e determina o possível. E este impossível não seria um a mais que tornaria sempre insuficiente o possível. Seria um a menos, o dejeto, a sobra, o resto, o que não merece ser computado, o que parece não admitir formalização. ${ }^{21}$

Acontece no instante breve em que eu, que sei da inserção, observo o "trocador", ou consumidor-espectador-artista em potencial, receber o objeto em suas mãos sem sabê-lo denso. Nesse instante, autor e trocador compartilham um abismo na experiência. Aliás, pouco importa quem é o autor, de fato, da inserção, pois aprendi observando que converte-se automaticamente em autor aquele que sabe que tem uma inserçáo em máos e, conscientemente, opta por reintroduzi-la no circuito, passando a acompanhar sua movimentação. A autoria não está no gesto de carimbar, mas no ato consciente, multitudinário, de trocar. Metidos nesse curto-circuito, autor e trocador têm de se confrontar com algo menos que um rasgo na superfície. O trocador observa sem entender o que está inserido na nota; e o autor observa atentamente uma nova expressão se formar no rosto do trocador. Os gestos de ambos tateiam, em conjunto, um novo lugar no espaço e adquirem certa beleza definitiva. Aí, quando esse rasgo é menos que um rasgo na superfície do objeto, quando ainda não disse a que veio mas já se antevê algo de sua aparição artística, torna-se visível, através dos gestos de ambos, o zero deflagrador.

\footnotetext{
Mas o importante não é lançar uma reforma mas uma experiência de ruptura completa com esta sociedade; uma experiência que não dure mas que deixe entrever uma possibilidade: percebe-se algo, fugidiamente, que depois se extingue. Mas basta para provar que esse algo pode existir. ${ }^{22}$
}

\section{Referências}

AGAMBEN, Giorgio. O homem sem conteúdo. Belo Horizonte: Autêntica, 2012.
21 BRITO, Ronaldo. "Frequência Imodulada”, 1981, p. 8.

22 SARTRE, Jean-Paul. "A Expansão do Campo do Possível”, 2008, p. 23. 
BARTHES, Roland. Mitologias. São Paulo: Difusão Europeia do Livro, 1972.

BRITO, Ronaldo. "Freqüência Imodulada". In: Cildo Meireles. Rio de Janeiro: Funarte, 1981, p. 8.

CAMPOS, Augusto de; PIGNATARI, Décio; CAMPOS, Haroldo de. Teoria da poesia concreta: textos críticos e manifestos 1950-1960. São Paulo: Brasiliense, 1987.

DUCHAMP, Marcel. "O Ato Criador". In: BATTCOCK, Gregory. A Nova Arte. São Paulo: Perspectiva. 2004, p. 73.

KLEIN, Naomi; VINAGRE, Ryta. Sem logo: a tirania das marcas em um planeta vendido. Rio de Janeiro: Record, 2002.

MEIRELES, Cildo; SCOVINO, Felipe (Org.). Encontros: Cildo Meireles. Rio de Janeiro: Azougue, 2009

Bravo Online, jul. 2006. Entrevista concedida a Fernando Oliva. Disponível em: http://www.canalcontemporaneo.art.br/brasa/archives/000795.html Acesso em 22 de setembro de 2017.

MELENDI, Maria Angélica. "Garrafas no mar, da urgência à desesperança”. Grupo :: Estratégias da Arte numa Era de Catástrofes. Belo Horizonte, 2002. Disponível em: https://www.eba.ufmg.br/grupo/textopiti04.htm. Acesso em 22 de setembro de 2017.

SCOVINO, Felipe. "A ironia e suas estratégias na obra de Cildo Meireles". Arte \& Ensaios, Revista do Programa de Pós-Graduação em Artes Visuais EBA, UFRJ. Ano XIV, número 15, 2007.

SARTRE, Jean-Paul. "A Expansão do Campo do Possível”. In: PIMENTA, Heyk; COHN, Sérgio (Org.). Maio de 68. Rio de Janeiro: Beco do Azougue, 2008, p. 23.

Submissão: 07/09/2017

Aceite: 07/06/2018

https://doi.org/10.5007/2176-8552.2017n24p112

126 - outra travessia 24 - Programa de Pós-Gradução em Literatura 